\title{
THE MOLLUSCA OF FUNAFUTI.
}

(SUPPLEMENT.)

By CHARLES HEDLEY,

Conchologist, Australian Museum. 



\title{
THE MOLLUSCA OF FUNAFUTI.
}

\section{(SUPPLEMENT, )}

\author{
By Charles Hedlex,
}

Conchologist, Australian Museum.

In the year 1897, a second, and in 1898, a third expedition visited the Atoll of Funafuti in prosecution of the attempt to carry a bore through the coral formation. The mollusca herein described were obtained by these parties, chiefly by deep dredging, and were remitted to the Australian Museum by the Local Funafuti Committee of the Royal Society. This material reached the Writer too late for incorporation in the body of this Memoir. The results of a study of it are accordingly presented in this appendix.

This material is of importance since it illustrates a side of the Funafuti zoology which I had little opportunity of investigating personally, viz., that of the deeper water. Dredgings carried out by Mr. G. H. Halligan in one hundred and fifty fathoms, and again in two hundred fathoms, produced results of especial interest. In the latter depth he discovered a bed of the typical "Pteropod Ooze." The sample of his dredgings submitted to me, might have stood for the portrait of that deposit figured by Murray and Renard.*

This ooze has been chiefly. studied in the Atlantic, and though its equal distribution in the Pacific is a matter of course, the present record is an interesting extension of the known range.

But the chief claim that this deposit has on our attention is that it appears in water of less depth than in any instance known heretofore. The least depth in which the "Challenger" obtained Pteropod Ooze was in 390 fathoms, the greatest 1,525 fathoms, the average being 1,044 fathoms. $\dagger$

The following species already noted as from surface waters again occurred in greater depths:

Teinostoma tricarinatum-150 fathoms off Beacon Islet (Funamanu), and 36 fathoms north of Pava Islet.

Cisonella ovata-150 fathoms off Beacon Islet (Funamanu).

Stomatella sanguinea-36 fathoms N. $30^{\circ}$ West of Pava, $45-52$ fathoms off Tutaga Islet.

*Murray and Renard-Chall. Rep., Deep Sea Deposits, 1891, pl. xi. fig. 6.

† Murray and Renard-loc. cit., p. 225. 
Caccum vertebrale-off Tutaga in $45-52,50-60$, and 200 fathoms; off Beacon Islet (Funamanu), at 150; and in 36 fathoms north; and 36 fathoms N. $30^{\circ} \mathrm{W}$. of Pava. This is evidently from its abundance a native of the deeper water. Some of the examples from 150 and 200 fathoms have a few brown blotches on the shell.

Caccum gulosum-dredged at every station with C. vertebrale.

Columbella varians -36 fathoms N. $30^{\circ}$ W. of Pava.

Marginella iota-36 fathoms N. $30^{\circ} \mathrm{W}$. of Pava, off Beacon Islet (Funamanu) in 150, and off Tutaga in $45-52$ and 200 fathoms.

Marginella sandwicensis - 150 fathoms off Beacon Islet (Funamanu).

Oivella simplex-36 fathoms N. of Pava.

Those species which are either new to science or have not been yet recorded from Funafuti are as under.

\section{CEPHALOPODA.}

Octopus tonganus, Hoyle.

Hoyle, Chall. Rep., Zool., xvi., 1886, p. 83, pl. viii., figs. 1, 2.

One male specimen was procured in the lagoon by Mr. A. EFinckh. The species has only been found before at Tonga.

\section{POLYPLACOPHERA.}

Tonicia $s p$.

(Fig. 59.)

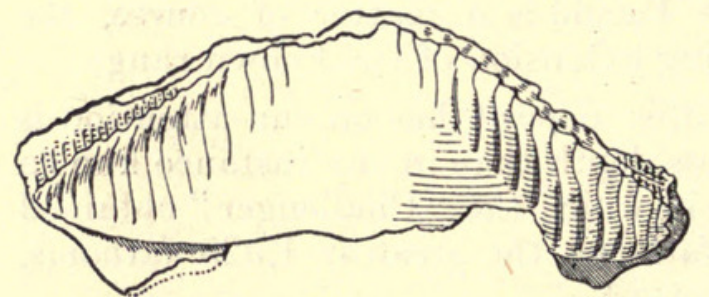

Fig. 59.

A single mutilated median valve of a Chiton was obtained at a depth of 150 fathoms off Beacon Islet (Funamanu). Such features as it has, point to an affinity with $T$. confossa, Gould. The rarity of this group in

the Central Pacific renders the occurrence of this fragment noteworthy. Only six species were known to Harper Pease from the Central Pacific. In his last paper he stated that,-_ "The absence of Chitonidæ from Polynesia has been noticed by authors as a remarkable fact, abounding as they $\mathrm{do}^{*}$ in the surrounding provinces, especially on the west coast of America, at Australia and New Zealand." $\dagger$

* The Chitons not the authors.

† Pease-Am. Journ. Conch., vii., 1872, p. 194. 


\section{SCAPHOPODA.}

Cadulus aratus, $s p$. nov.

(Fig. 60.)

Shell short and stout, slightly swollen and gently tapering to either end, on one side almost straight, on the other arcuate, glossy and almost transparent. In one case the translucent ground is mottled with opaque white spots. Four longitudinal equally spaced furrows impress the surface. Anal end bilabiate, the lips usually widely parted, that on the straighter side projecting beyond its fellow. In one case the lips are of equal length almost touching distally and divided by a narrow slit. Aperture very oblique with a small thickened rim. Length 3.4 ; breadth $.64 \mathrm{~mm}$. Another specimen, length 2 ; breadth $\cdot 48 \mathrm{~mm}$.

Dredged 36 fathoms north of Pava Islet; 36 fathoms N. $30^{\circ} \mathrm{W}$. of Pava Islet; $50-60$ fathoms off Tutaga Islet and 150 fathoms off Beacon Islet (Funamanu).

The Fijian $C$. dichelus, Watson, a near relative, is twice as large, more bent and unfurrowed.

\section{GASTEROPODA.}

Scissurella equatoria, sp. nov.

(Fig. 61.)

Shell large for the genus, thin, trochiform, with gradate spire; frilled, projecting keels; compressed belt below the fasciole, and tumid base. Colour white. Whorls five. Sculpture-about eighty five, curved, oblique, lamellate ribs cross the whole shell Above, the spiral sculpture can hardly be traced, but on the base it is distinguishable as delicate, widely spaced threads overriding the ribs and latticing the interspaces. Fasciole enfolded by broad margins, which are fimbriated by the ribs. Umbilicus narrow, infundibuliform, deep. Aperture oblique, subquadrate; lip slightly and gently recurved; columella margin explanate and reaching over the umbilicus. Major diameter 3 , minor $2 \cdot 5$; height $2 \cdot 68 \mathrm{~m} . \mathrm{m}$.

One specimen dredged off Tutaga Islet in 200 fathoms.
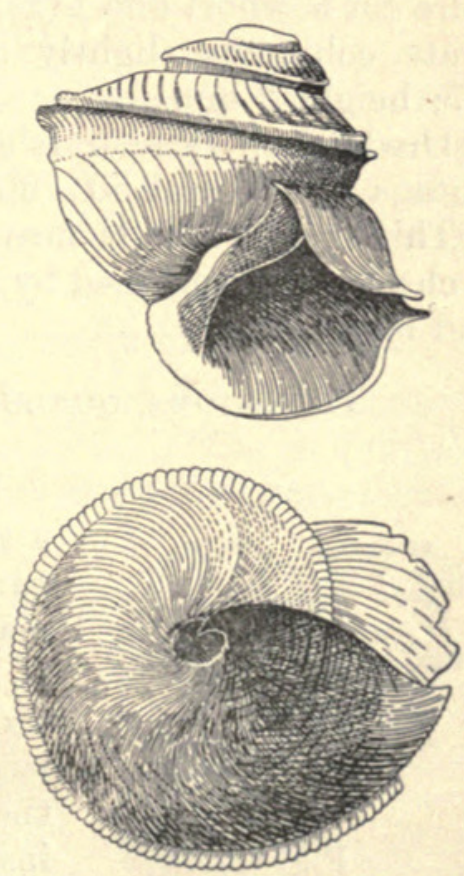

Fig. 61.

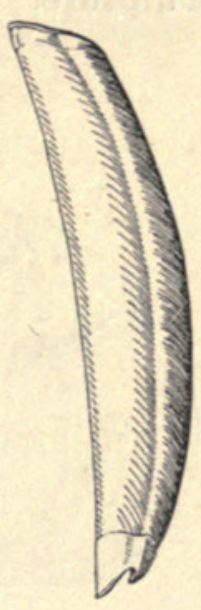

Fig. 60. 
This, the largest species of the genus, seems very close to $S$. äedonia, Watson, from which I separate it by the contracted zone beneath the fasciole, larger size and less development of spiral sculpture.

Schismope plicata, $s p$. nov.

(Fig. 62.)

Shell large for the genus, thin,

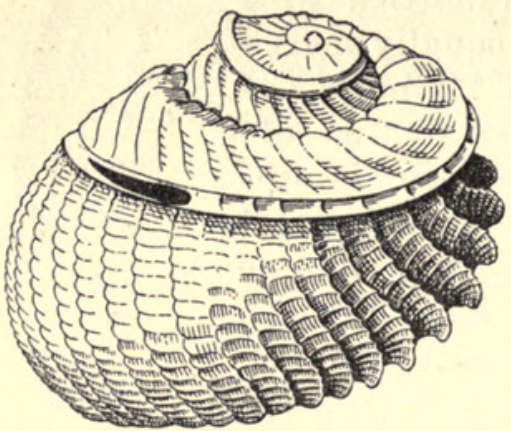

Fig. 62. subglobose, flattened above. Colour cream. Whorls three, rapidly increasing. Earlier whorls wound in the same plane, the last steeply descending, sharply angled at the fasciole, compressed and then inflated beneath it. Umbilicus moderate in width, deep, with smooth walls. Sculpture-both above and below the fasciole the shell is ornamented by about twenty-two prominent longitudinal ribs, which project most beneath the fasciole half a whorl behind the mouth, from thence on they diminish considerably. These are overridden by close, sharp, raised, spiral lines, which cross the interstices and denticulate the crests of the ribs. Slit pointed anteriorly, rounded posteriorly, in length about a sixth of the circumference of the shell. The fasciole, a broad gutter with raised margins, its trough septate by continuations of the longitudinal ribs, ascends the spire for a whorl and a half, as in other Pacific species. Aperture ovate, columella slightly reflected. Major diameter $2 \cdot 3$, minor $1 \cdot 7$; height $2 \mathrm{~mm}$.

Dredged off Beacon Islet (Funamanu), in 150 fathoms, and off Tutaga in 150 and 50-60 fathoms.

This species stands nearest to $S$. ferriezi, Crosse, from which it is clearly distinguished by a more elevated spire, coarser sculpture and larger size.

Thinostoma qualum, var. PaUcicostatum, var. nov.

(Fig. 63.)

Under this varietal name is distinguished

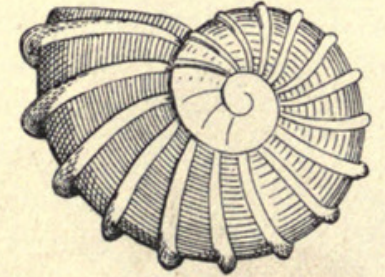

Fig. 63. a specimen, which, though probably immature is larger than the type, measuring in major diameter 2 and in minor $1.32 \mathrm{~mm}$. It has the same detail sculpture but carries sixteen ribs on the last whorl instead of twenty. The chief distinction however is that the ribs are continued to the suture instead of terminating at a distance therefrom as in the type.

Dredged at 150 fathoms off Beacon Islet (Funamanu). 


\section{Haliotis ovina, Chemnitz.}

Pilsbry, Man. Conch., xii., 1890, p. 125, pl. xix., figs. 7, 8 .

A specimen was obtained at Funafuti by Mr. A. E. Finckh.

\section{Teinostoma parvulum, $s p$. nov.}

(Fig. 64.)
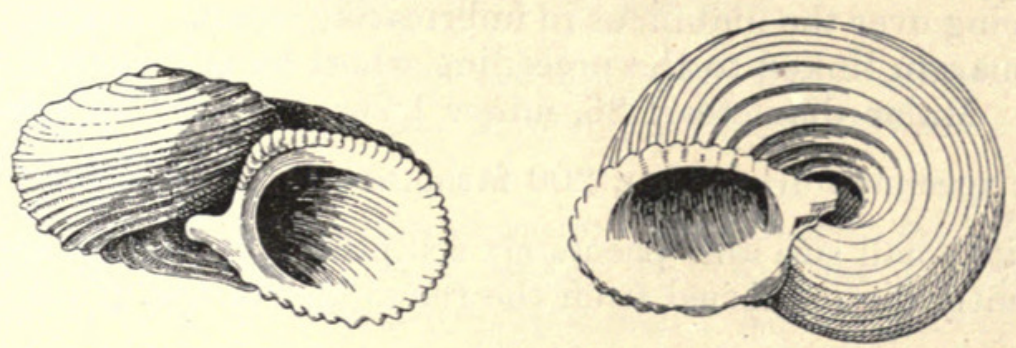

Shell minute, solid, depressed turbinate, with slightly elevated spire. Colour cream. Whorls four. Sculpture-about fourteen elevated, spiral lyræ which are weaker and widest apart above and closer and stronger towards the umbilicus. Above and on the periphery, their interstices are occupied by one or two fine spiral threads. No transverse sculpture is apparent. Base rounded. Umbilicus oblong, narrow, deep; the basal sculpture winding obliquely into

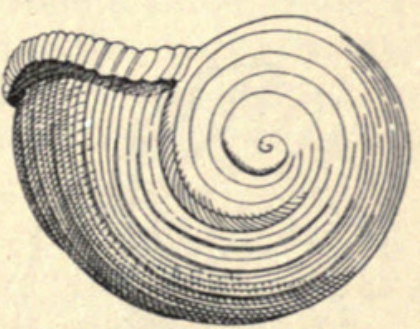

Fig. 64. it. Aperture oblique, circular, with a smooth, inner, raised margin and a stout varix alternately and evenly grooved and ridged by the spiral sculpture. The left lower margin of the varix is produced in a tongue over the umbilicus. Major diameter $1 \cdot 14$, minor 1 ; height $\cdot 8 \mathrm{~mm}$.

One specimen dredged in 36 fathoms north of Pava Islet.

This species, the least of the genus to which I have assigned it, has an equal claim to be placed in Liotia. The subumbilical tongue, a rather artificial feature, has governed the present generic disposition.

\section{Teinostoma rotatum, $s p$. nov.}

Shell small, perforate, subdiscoidal. Colour white. Whorls three and a half, rounded, gradually increasing, last descending

(Fig. 65.)

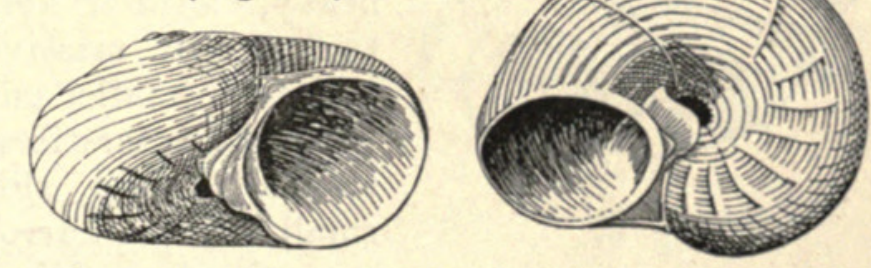

Fig. 65 . 
and contracting at the aperture. First two whorls smooth, the rest sculptured by about forty, fine, close, even, flat-topped, spiral lyræ; parted by sharp, narrow interstices. On the base are eight, raised, radiating bars of callus, unevenly set round the umbilicus, like the spokes of a wheel. A fifth of a whorl behind the aperture the scar of a former aperture has left a kind of varix. Umbilicus small, its margin crenulate. Aperture oblique, circular, entire; left margin barely recurved; lower right margin advancing over the umbilicus in imbricating callous tongues; upper right margin linked to the preceding whorl by a $\mathrm{V}$-shaped callous ridge. Major diameter 1.86 , minor 1.76 ; height $1.16 \mathrm{~mm}$.

One specimen dredged in 200 fathoms off Tutaga Islet.

By its small size and peculiarly sculptured base, this species is sufficiently distinguished from the remainder of the genus.

\section{Liotia $s p$.}

(Fig. 66.)

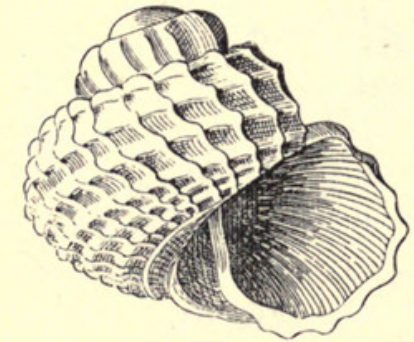

Fig. 66.

Shell globose, rather flattened on the base. Colour cream. Whorls three. Sculpture-eight equally spaced spiral lyræ, cancellated by the intersection of about eighteen longitudinal ribs of equal size. Umbilicus narrow. Aperture unfinished. Major diameter $1 \cdot 16$, minor $1 \cdot 6$; height $1 \cdot 16 \mathrm{~mm}$. Islet.

One specimen in 200 fathoms off Tutaga

This shell, though not adult, is evidently new. Its future recognition should be ensured by the remarkable sculpture. Probably it belongs near Liotia and possibly to the new genus Mecoliotia. Until the important characters of the aperture are known, no good end would be served by bestowing on it a specific name.

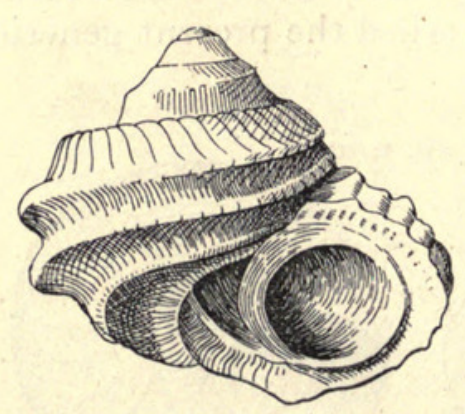

Fig. 67.

\section{Liotia parvissima, $s p$. nov.}

(Fig. 67.)

Shell minute, solid, turbinate. Colour cream. Whorls four. Sculpture-a heavy, elevated keel on the shoulder, two equally massive on the periphery, and two smaller on the base. Across keels and interstices run distant, longitudinal, raised threads. Umbilicus small, oblique narrow and deep. Aperture, circular, oblique, with a short but 
heavy varix, crenulated by the spiral sculpture. Major diameter $\cdot 84$, minor $\cdot 66$; height $\cdot 84 \mathrm{~mm}$.

Dredged off Tutaga Islet at a depth of 200 fathoms, and off Beacon Islet (Funamanu) at 150 fathoms.

This, the smallest known Liotia, is well distinguished by its simple and massive sculpture.

\section{MECOLIOTIA, gen. nov.}

A genus of the Liotiidæ, distinguished from Liotia by an elevated spire of six whorls, an obliquely truncate base and granose sculpture.

The type species appears to me to be co-generic with Iphitus tuberculatus, Watson.* ${ }^{*}$ The genus Iphitus was founded by Jeffreys on a single immature specimen, $\dagger$ and is known from Watson's rather than from Jeffreys' account. Jeffreys placed the genus in the Littorinidæ and Fisher in the Fossaridæ. My species cannot enter either of these families, nor, I should think, could $I$. tuberculatus. We are however, relieved from the unsatisfactory genus of Jeffreys by the fact that Iphitus is preocupied in Mollusca by Rafinesque. $\ddagger$ In Hemiptera Stäl introduced Iphita in $1870 . \S$

Type, Mecoliotia halligani.

\section{Mecoliotia halligani, sp. nov.}

(Fig. 68.)

Shell small, most massive, conical, with obliquely truncate base, narrowly perforate. Colour white. Whorls six of which two are apical, separated by deeply impressed sutures. Sculpturethe third has one, the fourth and fifth each two, and the last whorl three, prominent, heavy, spiral keels. These are overridden and knotted by longitudinal ribs, which on the last whorl number seventeen, cross from umbilicus to suture, and mount the upper whorls perpendicularly and continuously. Deep square pits are enclosed by the inter-

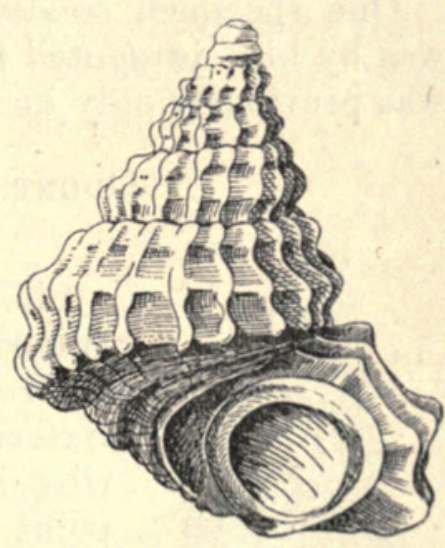

Fig 68. section of this sculpture. The first whorl is rounded, the second keeled. The base is hollow beneath the periphery, with a central

* Watson-Chall. Rep., Zool., xv., 1886, p. 583, pl. xlvi., fig. 5 .

† Jeffreys--Proc. Zool. Soc., 1883, p. 113, pl. xx., fig. 12.

‡ Rafinesque-Anal. Nat., 1815, p. 141.

$\S$ Stäl-Sv. Ak. Handl., 1870, p. 99. 
nodose lyra, then a furrow, followed by the smooth raised margin of the narrow oblique umbilicus. Aperture, oblique, circular with a double lip, one within the other, and an expanded, trifid wing-like varix. Length 1.6 ; breadth $1.4 \mathrm{~mm}$.

One specimen dredged off Tutaga Islet in 50-60 fathoms.

Named in honour of Mr. G. H. Halligan, who procured most of the deeper water species mentioned in this supplement.

\section{Eulima diaphana, sp. nov.}

(Fig. 69.)

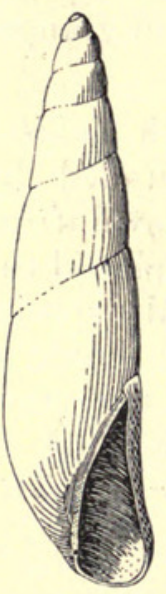

Fig. 69.

Shell narrow, subulate, transparent. Whorls seven, rapidly increasing, wound more obliquely as the growth proceeds. Surface smooth, most glossy, through it is seen every detail of the columella. Aperture somewhat claw-shaped, narrow and curved, acuminate posteriorly, broadest and truncate anteriorly. Outer lip sharp sinuous. Columella slightly curved, spreading a callus on the preceding whorl. Length 1.8; breadth $\cdot 44 \mathrm{~mm}$.

One specimen dredged at $45-52$ fathoms off Tutaga.

This species appears to be widely different from any hitherto figured.

\section{Eulima samonnsis, Crosse.}

Tryon, Man. Conch., viii., 1886, pl. lxx., fig. 78.

One specimen collected by Mr. W. Poole on the lagoon beach was by him presented to the Australian Museum. The species was previously only known from Samoa.

Odontostomia robusta, sp. nov.

(Fig. 70.)

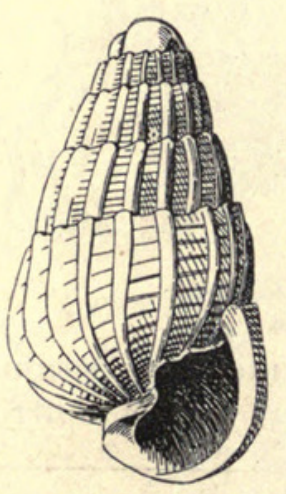

Fig. 70.

Shell small, strong, ovate. Colour white. Whorls four; exclusive of the smooth, prostrate, heterostrophic two-whorled apex. Sculpturesixteen strong, smooth, outstanding, longitudinal ribs sinuate the suture and reach to the extreme point of the base. Similar ribs extend continuously across the upper whorls. Between these ribs appear the broken lengths of about a dozen, delicate, widely parted, raised, spiral threads. Aperture ear-shaped, effuse anteriorly. Columella massive, entering in a strong, spiral twist. Lip formed by the last rib. Length $1 \cdot 2$; breadth $65 \mathrm{~mm}$.

One specimen dredged off Tutaga Islet in $45-52$ fathoms. 
This species is most like 0 . oodes, Watson, from which it is separated by more conical shape, fewer ribs and different apex.

Odontostomia Biplicata, sp. nov.

(Fig 71.)

Shell oblong-ovate, imperforate, white. Whorls three and an inrolled vertical and half buried apex, slightly gradate, separated by a channeled suture. Upper whorls angled and contracted above the suture. Last whorl slightly angled at the periphery. Sculpturelast whorl with two small, but sharp revolving ridges, one at the periphery and the other below the suture, both ascending the earlier whorls. Upper whorls otherwise smooth, final whorl furrowed spirally by about twenty-five fine close grooves beneath the periphery. Aperture ovate, acuminate above and below. Deep within the throat and confined to the posterior moiety, are five strong revolving ridges, the remainder of the throat is grooved

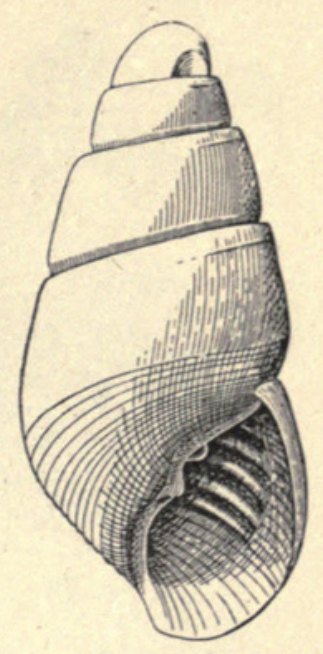

Fig. 71. by small revolving striæ, answering to the externals culpture. Lip sharp, simple, produced anteriorly. Columella with a heavy, median, transverse fold, posterior to which is another deeper oblique fold. Length $1 \cdot 46$; breadth $\cdot 7 \mathrm{~mm}$.

One specimen dredged at 36 fathoms north of Pava Islet.

This is a well marked species. Not only is it smaller than any enumerated in Tryon's Monograph, but the second, deep seated columella fold seems to be unmatched in the genus. The ridges in the throat occur in some species from the Red Sea.

\section{RISSOA FINCKHI, $s p$. nov.} (Fig. 72.)

Shell narrow, subulate, turretted, massive, small. Colour white with a yellow apex. Whorls eight. Sculpture-round the periphery of each whorl is wound a heavy tabulate keel. The penultimate whorl carries a spiral thread above and another below this keel. On the last whorl is a raised subsutural thread and three basal lyræ. Aperture oblique, circular, peristome entire, thickened and broadly reflected. Length 192 ; breadth $92 \mathrm{~mm}$.

One specimen dredged off Tutaga Islet in 200 fathoms.

Named in honour of Mr. A. E. Finckh, who made zoological collections on Funafuti

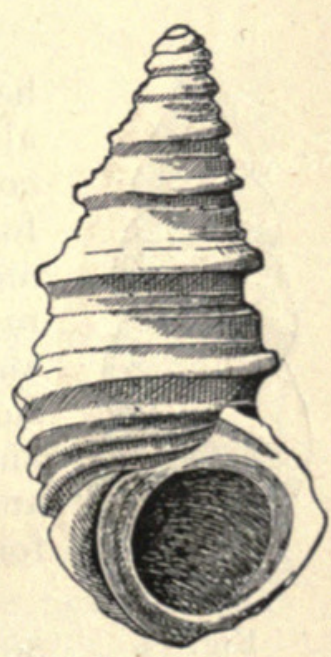

Fig. 72. 
in 1898 , when in charge of the Diamond Drill Boring Expedition.

\section{RisSoA POOLEI, $s p$. nov.}

(Fig. 73.)

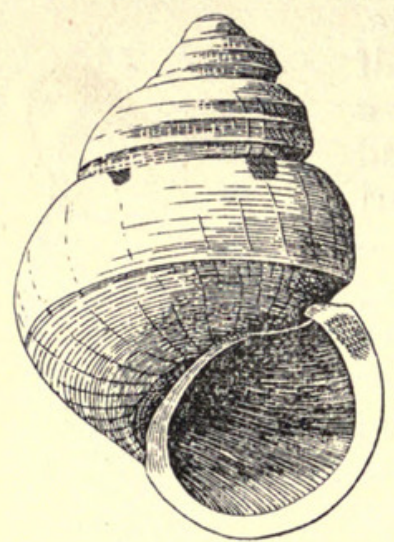

Fig. 73.

Shell broadly ovate. Whorls four. Colour white with a few subsutural orange dots, one of which occurs on the lip and three on the remainder of the last whorl. Sculpture-the last whorl is angled at a weak spiral rib on the periphery. Proportionately stronger are three on the penultimate, and two on the antipenultimate, similar spiral ribs. The whole shell is closely covered by minute, close, wavy, spiral threads which are overridden by faint, close, longitudinal sculpture extending across the whole whorl. Umbilicus small, covered by the columella. Aperture round, rather oblique. Lip massive, expanded and broadly reflected with a second lip or varix close behind. Columella broad appressed. Length .95 ; breadth $66 \mathrm{~mm}$.

Dredged off Tutaga Islet at depths of $45-52,50-60$, and 200 fathoms ; off Beacon Islet (Funamanu) at 150 fathoms; and north of Pava Islet at 36 fathoms.

The affinities of this shell are with the species previously described from Funafuti as Rissoa invisibilis. It is named in honour of Mr. William Poole, B.A., a volunteer assistant of the second expedition to Funafuti.

Diala profunda, $s p$. nov.

(Fig. 74.)

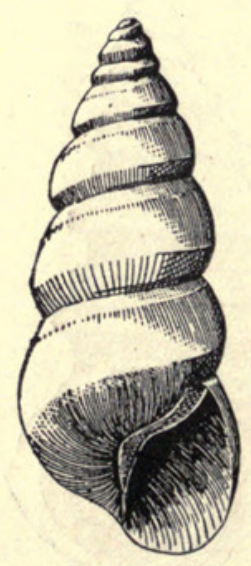

Fig. 74 .

Shell subulate, thin. Colour, the figured example has the first four whorls ochraceous, the next two almost white, the last two ochraceous buff with the columella and lip tawny ; another specimen is uniform dark brown. Whorls eight. The apex smooth and blunt; the third and fourth whorls with two raised spiral cords each, the remaining whorls angled above and below the suture. Surface smooth and shining. Aperture perpendicular, angled above, rounded below; outer lip straight and sharp; columella reflected over a minute perforation. Length 1.9 ; breadth $66 \mathrm{~mm}$.

Dredged off Tutaga Islet at depths of $45-50$, $50-60$ and 200 fathoms; and in 36 fathoms north and 36 fathoms N. $30^{\circ} \mathrm{W}$. of Pava Islet. 
Cæcum amaltheanum, $s p$. nov.

(Fig. 75.)

Shell small, a twisted cone, performing about a third of a revolution, rapidly enlarging. White very glossy, with about twenty, faint rib rings. Aperture circular, slightly contracted behind the everted lip. Septum gradate, with three steps, arising deep within the collar, peaked on the outer side. Length $\cdot 76$; breadth at aperture $\cdot 34 \mathrm{~mm}$.

Two examples dredged at 36 fathoms, north of Pava Islet.

The contour of this species isolates it from any co-generic type.

\section{Cecum legumen, $s p$. nov.}

(Fig. 76.)

Shell pod-shaped, arched on one side, nearly straight on the other; rounded in transverse section on the arched side and flattened on the straight. Colour white. Sculptured by fine growth rings, surface glossy and shining. At the aperture slightly contracted, mouth oval, flattened on one side. Septum much exserted, peaked on the curved side. As foreshortened to show the aperture in my drawing, the shell has a quaint resemblence to a tobacco pipe. Length 1.5 ; breadth $\cdot 64 \mathrm{~mm}$.

Dredged at 36 fathoms N. $30^{\circ} \mathrm{W}$. of Pava Islet

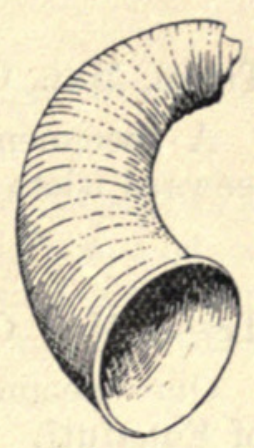

Fig. 75.
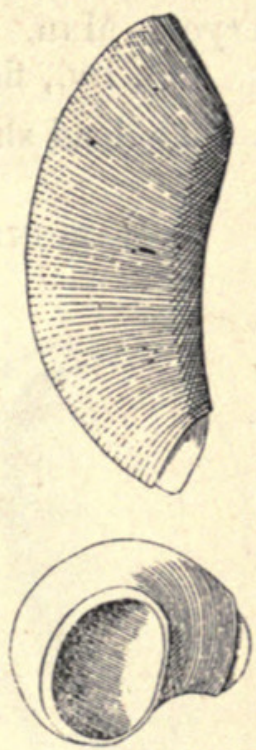

Fig. 76. and again at 150 fathoms off Beacon Islet (Funamanu).

The only species at all resembling this, figured in Tryon's Manual, is $C$. nitidum, Stimpson, than which it is less inflated.

\section{Triforis asperrimus, Hinds.}

(Fig. 77.)

Hinds, Ann. Mag. Nat. Hist., xi., 1843, p. 18 ; Tryon, Man. Conch., ix., 1887, p. 181, pl. xxxviii., fig. 6.

A single, probably immature, specimen of twelve whorls, in length 2.92 and in breadth $.56 \mathrm{~mm}$., which was dredged in 36 fathoms, north of Pava Islet is thus doubtfully determined. The species appears not to have been seen since Sir Edward Belcher dredged his unique specimen in eight fathoms on the Papuan coast.

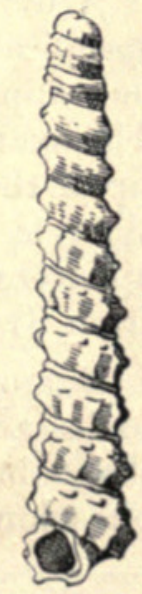

Fig. 77. 


\section{Murex ramosus, Linne.}

Tryon, Man. Conch., ii., 1880, p. 95, pl. i., figs. 1, 2.

A specimen was obtained by Mr. A. E. Finckh on one of the leeward islets of Funafuti.

\section{CyPRAA BECKI, Gaskoin.}

Tryon, Man. Conch., vii., 1885, p. 91, pl. xvii., figs. 86, 87.

One specimen collected by Mr. W. Poole on the lagoon beach of Funafuti.

\section{Turricula exasperata, Gmelin.}

Tryon, Man. Conch., iv., 1882, p. 180, pl. liii., figs. 541-544, pl. liv., figs. $545-546$.

One dead shell dredged in 36 fathoms N. $30^{\circ} \mathrm{W}$. of Pava Islet.

Marginella isseli, Nevill, var. ellicensis, var. nov.

(Fig. 78.)

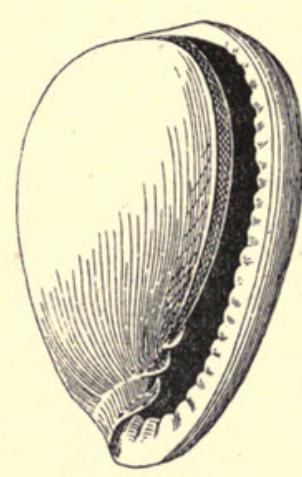

Fig. 78.

Shell small, ovate, white, smooth, with a buried spire. Aperture narrow, crescentic. Outer lip arching from and above the vertex, thickened without and finely crenulate within, channeled anteriorly. Inner lip with a heavy layer of callus edged abruptly. Columella with three oblique entering folds, the posterior one small. Length $1 \cdot 4$; breadth $\cdot 64 \mathrm{~mm}$.

Dredged at 36 fathoms north of Pava Islet, at 36 fathoms N. $30^{\circ} \mathrm{W}$. of Pava Islet, and at 150 fathoms off Beacon Islet (Funamanu)

After much perplexity I have concluded not to separate this specifically from $M$. isseli, Nevill, ${ }^{*}$ which agrees in size and shape but apparently differs by an additional fold on the columella. The example of that which Issel examined $\dagger$ had not the crenulated lip of the type. Savigny's work, containing the original description, is unfortunately inaccessible to me. No distinction is apparent to me ketween this species and $M$. nympha, Brazier, $\ddagger$ from Sydney Harbour,

Examples from Cape Sidmouth, Queensland, of what appears to be another variety of $M$. isseli are before me. They agree in shape but differ by being $2 \mathrm{~mm}$. in length, and by having five plications on the columella.

* Tryon-Man. Conch., v., 1883, p. 40, pl. xi., fig. 39.

+ Issel-Malac. del Mar Rosso, 1869, p. 117.

‡ Brazier-Proc. Linn. Soc. N. S. W., (2) ix., 1894, p. 168, pl. xiv., fig. 2. 


\section{Pterosoma plana, Lesson.}

Hedley, Proc. Malac. Soc., i., 1895, p. 333 ; Crosse, Journ. de Conch., xliv., 1896 (1897), pp. $207-212$.

An imperfect shell from a depth of 200 fathoms off Tutaga Islet, is with doubt so identified. Since writing the article above quoted I have found that Fischer's reason for classing this as a Nemertine was a mistaken identification by the Naturalists of the "Challenger."*

Atlanta gibbosa, Eydoux and Souleyet.

Eydoux and Souleyet, Voy. Bonite, Zool., ii., 1841, p. 386, p]. xxi., figs. $1-8$.

Dead shells were dredged off Tutaga, in 45-52 and 200 fathoms. This species does not seem to have been recorded from the Pacific.

Atlanta turriculata, D'Orbigny.

Eydoux and Souleyet, loc. cit., p. 391, pl. xxi., figs. $30-35$.

Dredged off Tutaga Islet in $45-52$ and 200 fathoms.

\section{Atranța guidichaudi, Eydoux und Souleyet.}

Eydoux and Souleyet, loc. cit., p. 397, pl. xix., figs. $29-34$.

Several dead shells dredged in 200 fathoms off Tutaga Islet.

ToRnatiNa LEPTEKES, Watson.

Pilsbry, Man. Conch., xv., 1893, p. 200, pl. xxiv., figs. 29, 30.

Dredged in 36 fathoms north of Pava Islet, and off Tutaga in $45-52$ and 200 fathoms.

Previously taken off Raine Island, Queensland, by the "Challenger,"

\section{Ringicula, $s p$.}

A small Ringicula was dredged in $45-52$ fathoms off Tutaga Islet. It corresponds exactly to specimens from Torres Straits, which I have identified as $P$. pusilla, Watson, and differs very little from my $R$. parvula. It may be here pointed out that the illustration of $R$. pusilla, $\uparrow$ appears to represent a young and broken shell, and that the description conveys a totally different idea of the species.

* Moseley-Ann. Mag. Nat. Hist., (4) xvi., 1875, p. 382.

† Watson-Chall. Rep., Zool., xv., 1886, pl. xlvii., fig. 9. 


\section{Ringicula incisa, $s p$. nov.}

(Fig. 79.)

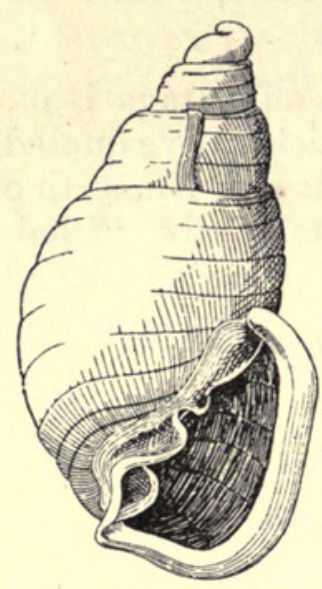

Fig. 79 .

Shell ovate, glossy. Whorls five. Colour white. Sculpture-girt around the last whorl are eight nearly equidistant sharp furrows, sloping above and cut square below so as to carve the surface into descending steps. On the upper whorls there are three furrows. A distinct varix marks the penultimate whorl. Aperture ear-shaped, effuse and truncate anteriorly. Outer lip broadly reflected, rather straight, without tubercles. Inner lip with broad and strong plications below and a small one above. Length $2 \cdot 2$; breadth $1.2 \mathrm{~mm}$.

One specimen dredged in 36 fathoms N. $30^{\circ}$ W. of Pava Islet.

Phyllidia varicosa, Lamarck.

Bergh, Reis. Archip. Philippinen, ii., 1876, p. 380, pl. lxxxvi., fig. 11.

Three specimens were collected by Mr. A. E. Finckh in the Funafuti lagoon.

\section{Cryptopthalmus smaragdinus, Leuckart.}

Pilsbry, Man. Conch., xvi., 1895, p. 37, pl. vi., figs. 29-36.

Two specimens were taken by myself alive in shallow water in the lagoon. Mention of them was inadvertantly omitted from preceding pages. With them were taken an undetermined Doris, and an Eolis.

\section{Limacina inflata, D'Orbigny.}

H. and A. Adams, Genera Recent Mollusca, iii., 1858, pl. cxxxvii., figs. 2, 2a, 2b; Pelseneer, Chall. Rep., Zool., xxiii., 1888, p. 17.

Dead shells were dredged in abundance, off Tutaga Islet, in 45 $-52,50-60$, and 200 fathoms ; in 36 fathoms north and in 36 fathoms N. $30^{\circ} \mathrm{W}$. of Pava; and in 150 fathoms off Beacon Islet (Funamanu).

\section{Limacina bulimoides, D'Orbigny.}

Rang and Souleyet, Hist. Nat. Pteropodes, 1852, p. 65, pl. xv., figs. $1-7$; Pelseneer, loc. cit., p. 30.

Dead shells dredged plentifully off Tutaga Islet in $36,45-52$ and 200 fathoms, and N. $30^{\circ}$ W. of Pava Islet in 36 fathoms.

\section{Clio virgula, Rang.}

Rang and Souleyet, loc. cit., p. 57, pl. vi., fig. 2, pl. xiii., figs. 20 - 24; Pelseneer, loc. cit., p. 48. 
A few shells dredged off Tutaga Islet in $45-52$ and 200 fathoms and off Beacon Islet in 150 fathoms.

\section{Clio acicula, Rang.}

Rang and Souleyet, loc. cit., p. 56, pl. vi., figs. 5, 7; Pelseneer, loc. cit., p. 51.

A few dead shells dredged in 200 fathoms off Tutags Islet.

Clio striata, Rang.

Rang and Souleyet, loc. cit., p. 55, pl. vi., fig. 3; Pelseneer, loc. cit., p. 51 .

One broken specimen from 45 - 52 fathoms off Tutaga Islet.

Clio subula, Quoy and Gaimard.

Rang and Souleyet, loc. cit., p. 55, pl. vi., fig. 1; Pelseneer, loc. cit., p. 57.

Numerous dead shells dredged off Tutaga Islet in $45-52$ and 200 fathoms.

\section{Clio pyramidata, Linne.}

Rang and Souleyet, loc. cit., p. 50, pl. v., figs. 7 -11; Pelseneer, loc. cit., p. 63 .

Dredged off Tutaga Islet in 45 - 52 and 200 fathoms.

Cuvierina columnella, Rang.

Boas, Spolia Atlantica, 1885, pl. iii., fig. 39; Pelseneer, loc. cit., p. 67.

One specimen dredged in 200 fathoms off Tutaga Islet.

\section{Cavolinia quadridentata, Lesueur.}

Boas, loc. cit., p. 99, pl. i., fig. 4, pl. ii., fig. 15; Pelseneer, loc. cit., p. 78.

A few dead specimens dredged off Tutaga Islet, in $45-52$ and 200 fathoms.

\section{Cavolinia longirostris, Lesueur.}

Boas, loc. cit., p. 102, pl. i., fig. 5, pl. ii., fig. 16; Pelseneer, loc. cit., p. 79 .

One dead specimen dredged in 200 fathoms off Tutaga Islet.

\section{Cavolinia inflexa, Lesueur.}

Boas, loc. cit., p. 123, pl. i., fig. 11, pl. ii., fig. 21; Pelseneer, loc. cit., p. 85.

Dredged off Tutaga Islet in $45-52$ and 200 fathoms. 
Agadina stimpsoni, A. Adams.

Pelseneer, loc. cit., p. 31, pl. i., figs. $11-14$.

A few specimens dredged off Tutaga Islet in $45-52$ and 200 fathoms and north of Pava in 36 fathoms.

\section{PELECYPODA.}

\section{ArCa PTERoEssa, Smith.}

Smith, Chall. Rep., Zool., xiii., 1885, p. 262, pl. xvii., fig. 4.

Two small separate valves were dredged at 200 fathoms off Tutaga Islet.

\section{Arca Congenita, Smith.}

Smith, loc. cit., p. 264, pl. xvii., fig. 6 .

One small valve from 50 - 60 fathoms off Tutaga Islet.

\section{Limopsis Davidis, $s p$. nov.}

(Fig. 80.)

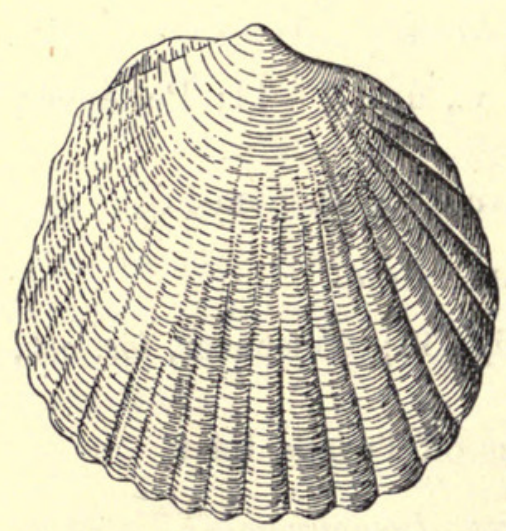

Shell small, suborbicular, flattened, scarcely inequilateral. Colour white, with a few, small, scattered brown dots. Posterior margin truncate; ventral and anterior margins rounded. Umbo prominent. Epidermis denuded. Sculpture-about twentyfour, prominent, radiating ridges sharply crenulate the margin and fade away before reaching the umbo, these are separated by flat interstices of about twice their breadth. They are

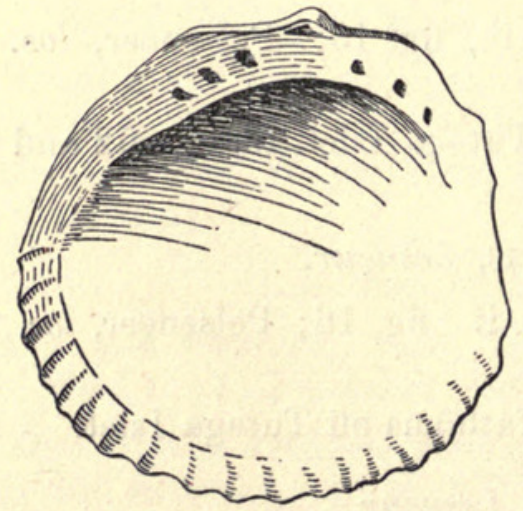

Fig. 80. more prominent and closer together at the posterio-ventral side, but for a space in the posterior slope one or two seem missing. The whole valve is covered with close concentric wrinkles, which become coarser as the ventral margin is approached. Hinge area very broad and rather curved, teeth three on each side. Internal margin crenulate. Height $1 \cdot 22$, length $1 \cdot 22 \mathrm{~mm}$.

One valve from $45-52$ fathoms off Tutaga Islet.

Named in honour of Prof. T. W. E. David, B.A., under whose auspices it was secured. 
If adult this species is the smallest known member of the genus In several respects it approaches L. antillensis, Dall,* which is deeper, and has certain internal tubercles absent in $L$. davidis.

Limea pectinata, H. Adams.

H. Adams, Proc. Zool. Soc., 1870, p. 7, pl. i., fig. 11.

One valve from 36 fathoms N. $30^{\circ} \mathrm{W}$. of Pava.

This is the first appearance of either species or genus in the Pacific.

\section{Pecten speciosus, Reeve.}

Reeve, Conch. Icon., viii., pl. xxvii., sp. 112.

One living example was taken in the lagoon by Mr. A. E. Finckh.

Crassatella $s p$.

A fragment of a Crassatella which might belong to $C$. rhomboides, Smith, was taken off Tutaga in 50-60 fathoms.

ADDEnda.-Since revising the preceding pages, $I$ have found among the shells which I collected at Funafuti, the following additional species :-Engina lineata, Reeve; Sistrum dumosum, Conrad; and Sistrum undatum, Chemnitz.

* Dall-Bull. Mus. Comp. Zool, xii., 1886, p. 237, pl. viii., fig. 7 . 


\section{$2 \mathrm{BHL}$ Biodiversity Heritage Library}

Hedley, Charles. 1899. "The Mollusca of Funafuti. (Supplement)." The Australian Museum Memoir 3(9), 547-565.

https://doi.org/10.3853/j.0067-1967.3.1899.507.

View This Item Online: https://www.biodiversitylibrary.org/item/104834

DOI: https://doi.org/10.3853/j.0067-1967.3.1899.507

Permalink: https://www.biodiversitylibrary.org/partpdf/258424

\section{Holding Institution}

University of California Libraries (archive.org)

\section{Sponsored by}

MSN

\section{Copyright \& Reuse}

Copyright Status: NOT_IN_COPYRIGHT

This document was created from content at the Biodiversity Heritage Library, the world's largest open access digital library for biodiversity literature and archives. Visit BHL at https://www.biodiversitylibrary.org. 